\title{
ANTIBACTERIAL ACTIVITY OF ETHANOLIC AND AQUEOUS EXTRACTS OF FOUR MEDICINAL PLANTS ON THE IN VITRO GROWTH OF ESCHERICHIA COLI AND STAPHYLOCOCCUS AUREUS
}

Philomène Aya KOKORA ${ }^{1}$, *Jacques Auguste Alfred Bognan ACKAH ${ }^{1}$, Zinzindorf Yessé NANGA ${ }^{2}$ Mathieu Adou Koffi KRA ${ }^{1}$, Guillaume Yao LOUKOU ${ }^{2}$, Adama COULIBALY ${ }^{1}$, Joseph DJAMAN ${ }^{1,3}$

${ }^{1}$ Laboratoire de Pharmacodynamie - Biochimique, UFR Biosciences, Université de Cocody Abidjan,

${ }^{2}$ UFR des Sciences Pharmaceutiques \& Biologiques, Université de Cocody, Laboratoire National de la Santé Publique (Côte d'Ivoire)

${ }^{3}$ Departement de biochimique clinique et fondamentale, Institut Pasteur de Côte d'Ivoire. BP490 Abidjan 01

*Corresponding Author's Email: jacquackah@yahoo.fr

\begin{abstract}
Evaluation of antibacterial activity of four medicinal plants used in the treatment of diarrheal diseases. To determine the antibacterial activity of total aqueous and ethanolic extracts of different plants, agar diffusion (Muller-Hinton) and broth macrodilution (Muller-Hinton) methods( DMHB) were used tested on Staphylococcus aureus ATCC 25923 and Escherichia coli ATCC 25922 and two clinical strains Escherichia coli 18170 and Staphylococcus aureus 1315. The diameters of inhibition and minimum inhibitory concentrations were determined. The studies carried out by the method of agar diffusion method and the double dilution revealed that extracts of Terminalia mantaly H. Perrier (Combretaceae) has an inhibitory activity on all tested strains. The inhibitory diameters vary between $7.66 \mathrm{~mm}$ and $35 \mathrm{~mm}$. The minimum inhibitory concentrations (MIC) of the extracts ranged from $0.078 \mathrm{mg} / \mathrm{mL}$ and $2.5 \mathrm{mg} / \mathrm{mL}$. The ethanolic extracts inhibit the growth of bacteria at lower concentrations than the aqueous extracts. Terminalia mantaly has a stronger antibacterial activity and thus can be useful in the search for new molecules to fight against bacterial resistance.

Keywords: antibacterial activity, inhibition diameters, minimum inhibitory concentration, Terminalia mantaly
\end{abstract}

\section{INTRODUCTION}

In Africa, as elsewhere in the world, plants are widely used in the treatment of various ailments. Adjanohoun and Aké ${ }^{1}$ have identified more than 5000 medicinal plant species. The properties of some of them have long been exploited by people. In the olden days in Africa priests and medical doctors had the ancient manuscripts describing many herbal recipes ${ }^{8}$. The safety, dosage and usage description were passed down from generation to generation. Thus most of the diseases known by the populations had a corresponding treatment.

Today, traditional medicine rivaled with modern medicine despite the exploits of the latter. According to the World Health Organization (WHO), nearly $80 \%$ of people in developing countries depend on this traditional medicine for their primary health care needs due to the high cost of modern medicines ${ }^{11}$, this is justified by the fact that these herbal recipes continue to show their efficacy in healing many people. In Côte d'Ivoire people using traditional medicines is increasingly high due to, poverty of the population, prolong political instability, war and access to modern medicine for health care is becoming increasingly difficult.

However, knowledge of the healing power of plants by the people is acquired empirically 13,14 . They were unaware of the chemical composition of these plants and also various other properties they might possess. Thus, in order to provide a scientific justification for the utilization of these plants, verification of the efficacy and safety of medicinal plants through ethnopharmacological studies have been conducted by several scientific groups. Four plants were selected for the purpose of this study, in order to verify the validity of anti-infective qualities assigned to them. They are: Erigeron floribundus, Acanthospermum spidum, Melanthera scadens and Terminalia mantaly. The antibacterial activity of total aqueous and ethanolic extracts of these plants was determined in vitro on the growth of Escherichia coli (E. Coli) and Staphylococcus aureus (S. Aureus).

\section{MATERIALS AND METHODS}

\section{Plant material}

The leaves and bark of Erigeron floribundus (Asteraceae) (EF), Acanthospermum hispidum Schrank. (Asteraceae) (AH) Melanthera scadens Schum. \& Thonn. (Asteraceae) (MS) and Terminalia mantaly H.Perrier (Combretaceae) (LYTER) were collected, dried and transformed into powder. All plants used in this study were provided by traditional healers in Côte d'Ivoire and identified by the National floristic Center University of Cocody Abidjan. The homogenates obtained were used in the preparation of different extracts.

\section{Microorganisms used}

The strains used for the purpose of these study are widely found in various human pathologies. They were 
supplied by the National Laboratory of Public Health. Different strains are shown in Table 1.

Table 1: Bacterial Strains

\begin{tabular}{|c|c|c|}
\hline Strains & Origin & Antibacterial profile \\
\hline E. coli ATCC 25922 & Collection & $\begin{array}{l}\mathrm{AMX}^{S} \mathrm{AMC}^{S} \mathrm{TIC}^{S} \mathrm{TCC}^{S} \mathrm{PIP}^{S} \mathrm{CF}^{S} \mathrm{FOX}^{S} \mathrm{CTX}^{S} \mathrm{CAZ}^{S} \mathrm{ATM}^{S} \\
\mathrm{GM}^{S} \mathrm{TM}^{S} \mathrm{~K}^{S} \mathrm{AN}^{S} \mathrm{NET}^{S} \mathrm{TE}^{S} \mathrm{CS}^{S} \mathrm{SXT}^{S} \mathrm{NA}^{S} \mathrm{PEF}^{S} \mathrm{CIP}^{S}\end{array}$ \\
\hline E. coli 28170 & ECBU & $\begin{array}{l}\mathrm{AMX}^{\mathrm{R}} \mathrm{PIP}^{\mathrm{R}} \mathrm{CF}^{\mathrm{R}} \mathrm{CXM}^{\mathrm{R}} \mathrm{CMX} \mathrm{TM}^{\mathrm{R}} \mathrm{TM}^{\mathrm{R}} \mathrm{NET}^{\mathrm{R}} \mathrm{SXT}^{\mathrm{R}} \mathrm{NA}^{\mathrm{R}} \mathrm{PEF}^{\mathrm{R}} \\
\mathrm{NOM}^{\mathrm{R}}\end{array}$ \\
\hline S. aureus ATCC 25923 & Collection & $\begin{array}{l}\mathrm{P}^{S} \mathrm{AM}^{S} \mathrm{AMX}^{S} \mathrm{AMC}^{S} \mathrm{OX}^{S} \mathrm{TIC}^{S} \mathrm{CTX}^{S} \mathrm{GM}^{S} \mathrm{~K}^{S} \mathrm{TM}^{S} \mathrm{TE}^{S} E^{S} \mathrm{SP}^{S} \\
\mathrm{~L}^{S} \mathrm{CIP}^{S}\end{array}$ \\
\hline S. aureus 1326 & Cathéter central & $\mathrm{PT}^{\mathrm{R}} \mathrm{P}^{\mathrm{R}} \mathrm{L}^{\mathrm{R}} \mathrm{E}^{\mathrm{R}} \mathrm{RA}^{\mathrm{R}} \mathrm{K}^{\mathrm{R}} \mathrm{TM}^{\mathrm{R}} \mathrm{GM}^{\mathrm{R}}$ \\
\hline
\end{tabular}

ECBU: Urine culture, ATCC Américan Type Culture Collection, R: resistant, AMC: Amoxicillin + Clavulanic acid, PIP: Piperacillin, CF: Cephalothin, CXM: Cefuroxime, CMX: cefmenoxime, TM: tobramycin, NET netilmicin, TE : Tetracycline, SXT: + Trimethoprim Sulfonamides, NA: Nalidixic acid, PEF: pefloxacin, NOR: Norfloxacin, PT: pristinamycin, P:

\section{Preparation of extracts}

The extracts were prepared according to the method described by Zihiri and Kra ${ }^{17}$. For the preparation of total aqueous and ethanolic extracts $70 \%, 100 \mathrm{~g}$ of plant powder were extracted in one liter of distilled water (or a mixture of ethanol - water (70/30)) by maceration using a magnetic agitator (the process is repeated 3 times). The homogenate obtained was first spun in a square of fabric, and then filtered twice in succession on cotton wool and once on Whatman $3 \mathrm{~mm}$ paper. The filtrate was concentrated using a rotary evaporator at $70^{\circ} \mathrm{C}$. The concentrate was evaporated at $50^{\circ} \mathrm{C}$. in an oven for 48 hours. The extracts obtained from the total aqueous and ethanolic extracts $70 \%$. The various extracts obtained are: Aqueous extracts: EFaq, ASaq MSaq and LYTERaq; Ethanolic Extracts 70\%: EFeth, Aseth, Mseth and LYTEReth.

\section{Determination of antibacterial activity}

\section{Agar diffusion method}

The agar diffusion Muller-Hinton in agar plates was used to evaluate the activity of different extracts obtained. Culture medium has been in contact with inocula (prepared from pure culture of 18 to 24 hours) density of 0.5 McFarland approximately $10^{6} \mathrm{CFU} / \mathrm{ml}$ for 5 minutes. The petri dishes were then dried for 15 minutes
Penicillin G, L: Lincomycin, E: Erytromycine, C: Chloremphenicol, RA: Rifampicin, K: Kanamycin, TM: Tobramycin, GM: gentamicin, CIP: ciprofloxacin, AMX Amoxicillin ICT Tecarcilline, CTX: cefotaxime, OX: Oxacillin, TCC: Tticarcilline + clavulanic acid, FOS: Fosfomycin, CAZ: ceftazidime, ATM: aztreonam, AN: Amikcine, CS: Colistin.

at $37^{\circ}$ C. With sterilized object wells of $5 \mathrm{~mm}$ in diameter were punched in the agar, 6 wells maximum par each petri dish. $100 \mathrm{mg} / \mathrm{ml}$ extract solutions were prepared by diluting $100 \mathrm{mg}$ of extracts in $1 \mathrm{ml}$ of distilled water. $50 \mathrm{ml}$ of each extract solution were distributed into the wells. The plates are then incubated in an oven at $37^{\circ} \mathrm{C}$ for 18 to 24 hours.

\section{Method of double dilution in liquid medium}

The method of broth macrodilution (Muller-Hinton) was used to determine the minimum inhibitory concentration (MIC) of plant extracts. In a series of seven hemolytic tubes, $1 \mathrm{ml}$ of each extract concentration $(80 \mathrm{mg}$ to $0.078 \mathrm{mg} / \mathrm{ml}$ ) was added to each tube containing $1 \mathrm{ml}$ of Muller-Hinton broth and germ. The final concentration of extract varied between $40 \mathrm{mg} / \mathrm{ml}$ and $0.039 \mathrm{mg} / \mathrm{ml}$. Other two tubes were used as control tubes. One for sterility control containing $2 \mathrm{ml}$ of sterilized broth and other containing $2 \mathrm{ml}$ contaminated broth for growth control. The tubes were incubated at 37 ${ }^{\circ} \mathrm{C}$ for 18 to 24 hours. The MIC determination was performed by finding the difference between the turbidity values obtained before incubation (di) and those obtained after incubation (df) of each tube. These values were measured using a turbidimeter densimat type. When $\mathrm{df}-\mathrm{di}=0$ for $\mathrm{a}$ given tube then extract concentration of the tube corresponds to the MIC. 


\section{RESULTS AND DISCUSSION}

Table 2: Diameters of inhibition zones in mm extracts of Erigeron floribundus, Heliotropium indicum, Acanthospermum spidum, Melanthera scadens and Terminalia mantaly

\begin{tabular}{|c|c|c|c|c|c|}
\hline & Extract & $\begin{array}{c}\text { E. coli } \\
\text { ATCC } 25922 \\
\end{array}$ & 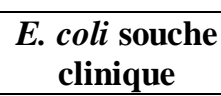 & $\begin{array}{c}\text { S. aureus } \\
\text { ATCC } 25923 \\
\end{array}$ & $\begin{array}{c}\text { S. aureus } \\
\text { souche clinique }\end{array}$ \\
\hline Erigeron & Aqueous & $<10$ & $<10$ & $\begin{array}{l}<10 \\
8\end{array}$ & $<10$ \\
\hline floribundus & Ethanolic & $<10$ & $<10$ & 28 & $11 \pm 0,57$ \\
\hline $\begin{array}{l}\text { Heliotropium } \\
\text { indicum }\end{array}$ & $\begin{array}{l}\text { Aqueous } \\
\text { Ethanolic }\end{array}$ & $\begin{array}{l}<10 \\
<10\end{array}$ & $\begin{array}{l}<10 \\
<10 \\
\end{array}$ & $\begin{array}{l}<10 \\
<10\end{array}$ & $\begin{array}{l}<10 \\
<10\end{array}$ \\
\hline $\begin{array}{l}\text { Acanthospermum } \\
\text { hispidum }\end{array}$ & $\begin{array}{l}\text { Aqueous } \\
\text { Ethanolic }\end{array}$ & $\begin{array}{l}<10 \\
<10\end{array}$ & $\begin{array}{l}<10 \\
<10\end{array}$ & $\begin{array}{c}<10 \\
12,33 \pm 1,52\end{array}$ & $\begin{array}{c}<10 \\
11,33 \pm 0,57\end{array}$ \\
\hline $\begin{array}{l}\text { Melanthera } \\
\text { scadens }\end{array}$ & $\begin{array}{l}\text { Aqueous } \\
\text { Ethanolic }\end{array}$ & $\begin{array}{l}<10 \\
<10 \\
\end{array}$ & $\begin{array}{l}<10 \\
<10 \\
\end{array}$ & $\begin{array}{c}<10 \\
24,66 \pm 5,03\end{array}$ & $\begin{array}{c}<10 \\
12,33 \pm 1,52\end{array}$ \\
\hline $\begin{array}{l}\text { Terminalia } \\
\text { mantaly }\end{array}$ & $\begin{array}{l}\text { Aqueous } \\
\text { Ethanolic }\end{array}$ & $\begin{array}{c}12 \\
14,33 \pm 0,57\end{array}$ & $\begin{array}{l}10,66 \pm 0,57 \\
12,33 \pm 0,57\end{array}$ & $\begin{array}{l}29 \pm 1 \\
35 \pm 1\end{array}$ & $\begin{array}{c}23 \pm 1 \\
30,66 \pm 1,15\end{array}$ \\
\hline
\end{tabular}

Table 3: Minimum Inhibitory Concentration (MIC) in $\mathrm{mg} / \mathrm{ml}$ extracts of Erigeron floribundus, Heliotropium indicum, Acanthospermum spidum, Melanthera scadens and Terminalia mantaly

\begin{tabular}{|l|c|c|c|c|c|}
\hline & Extraits & $\begin{array}{c}\text { E. coli ATCC } \\
\mathbf{2 5 9 2 2}\end{array}$ & $\begin{array}{c}\text { E. coli clinical } \\
\text { strain }\end{array}$ & $\begin{array}{c}\text { S. aureus } \\
\text { ATCC 25923 }\end{array}$ & $\begin{array}{c}\text { S. aureus clinical } \\
\text { strain. }\end{array}$ \\
\hline Erigeron floribundus & Aqueous & $>40$ & $>40$ & $>40$ & $>40$ \\
& Ethanolic & $>40$ & $>40$ & 20 & $>40$ \\
\hline Heliotropium indicum & Aqueous & $>40$ & $>40$ & $>40$ & $>40$ \\
& Ethanolic & $>40$ & $>40$ & $>40$ & $>40$ \\
\hline Acanthospermum & Aqueous & $>40$ & $>40$ & $>40$ & $>40$ \\
hispidum & Ethanolic & $>40$ & $>40$ & 40 & $>40$ \\
\hline Melanthera & Aqueous & $>40$ & $>40$ & $>40$ & $>40$ \\
Scadens & Ethanolic & $>40$ & $>40$ & 40 & $>40$ \\
\hline Terminalia & Aqueous & 0,625 & 2,5 & 0,3125 & 1,25 \\
Mantaly & Ethanolic & 0,3125 & 1,25 & 0,078 & 0,3125 \\
\hline
\end{tabular}

Agar diffusion method revealed that only Terminalia mantaly presented inhibitory activity on all strains tested. The diameter of the inhibition zones ranged from 7.66 $\mathrm{mm}$ to $29 \mathrm{~mm}$ for total aqueous extract and $11.33 \mathrm{~mm}$ to $35 \mathrm{~mm}$ for total ethanolic $70 \%$ extract (Table 1). The highest zones of inhibition are obtained on the strain of S. aureus ATCC 25923 and are $29 \mathrm{~mm}$ in diameter for LYTERaq and $35 \mathrm{~mm}$ diameter for LYTEReth. Total ethanolic extracts 70\% AHeth Mseth and EFeth showed inhibition zones on the strain of $S$. aureus ATCC 25923 with diameters of $12.33 \mathrm{~mm}, 24.66 \mathrm{~mm}$ and $28 \mathrm{~mm}$ respectively.

The results obtained with the method of double dilution in liquid medium confirmed the results obtained above. Terminalia mantaly is active in all strains. And that is represented by minimum inhibitory concentrations (MIC) obtained (Table 2). MIC values varied from $0.3125 \mathrm{mg} / \mathrm{ml}$ to $2.5 \mathrm{mg} / \mathrm{ml}$ for aqueous extract and from $0.078 \mathrm{mg} / \mathrm{ml}$ to $1.25 \mathrm{mg} / \mathrm{ml}$ for total ethanolic extract.

The analysis result shows that Terminalia mantaly has the strongest inhibitory activity than the other three plants regardless of the method used. No cases of resistance have been noted with the different extracts of this plant. This is verified by the inhibition diameters from $7.66 \mathrm{~mm}$ to $36 \mathrm{~mm}$ and MIC from $0.078 \mathrm{mg} / \mathrm{ml}$ to $2.5 \mathrm{mg} / \mathrm{ml}$. Thus MIC obtained with Terminalia mantaly are $0.078 \mathrm{mg} / \mathrm{ml}, 0.3125 \mathrm{mg} / \mathrm{ml}, 0.3125 \mathrm{mg} / \mathrm{ml}$ and $1.25 \mathrm{mg} / \mathrm{ml}$ respectively on $S$. aureus ATCC 25923 , $S$. aureus clinical strain, E. coli ATCC 25922 and E. coli clinical strain. The highest MIC (2.5 mg / ml) was obtained on the clinical strain of $E$. coli. These results are comprehensive, because according to Baba - Moussa et $\mathrm{al}^{6}$ and Mann et $\mathrm{al}^{10}$, most of the families Combretaceae species are known to contain antimicrobial compounds. Also the antibacterial activity of Terminalia mantaly had already been mentioned by Andrianstsoa and Andriantsiferana ${ }^{4}$. He revealed that the extract from the decoction of the leaves and stems of Terminalia mantaly inhibited the growth of Shiguella dysenteriae at concentration between $600 \mu \mathrm{g} / \mathrm{ml}$ and $800 \mu \mathrm{g} / \mathrm{ml}$. Yayé et al ${ }^{16}$ also showed that the total aqueous extracts and ethanolic $70 \%$ of this plant showed antifungal activity against Candida albicans at concentrations of 97.5 micrograms / $\mathrm{ml}$ and 48.75 micrograms / $\mathrm{ml}$.

The ethanolic extracts have a better antibacterial activity than the aqueous extracts and this regardless of the germ and the plant tested. The method of preparation of the ethanolic extract by the mixture of ethanol-water solvent (70/30) was initiated by Zihiri et al. ${ }^{17}$ Several studies including the Ahon et al. ${ }^{3}$, Ackah et al. ${ }^{2}$ and Yayé et al ${ }^{16}$ 
showed that ethanol $70 \%$ extract prepared by this method is more active than the aqueous extract. Our results therefore confirm theirs. This method therefore produces a better concentration of active ingredients.

\section{CONCLUSION}

This study has allowed us to determine the antibacterial properties of Erigeron floribundus, Acanthospermum hispidum, Melanthera scadens and Terminalia mantaly. It shows from these investigations that Terminalia mantaly is the most active plant among the four plants

\section{REFERENCES}

1. Adjanohoun E. J. et Aké Assi L. Contribution au recensement des plantes médicinales de Côte d'Ivoire, Université d'Abidjan, Centre National de Floristique (CNF), 1979: 358p.

2. Ackah J. A. A. B., Kra A. K.M., Zihiri G. N., Guédé - Guina F. Evaluation et essais d'optimisation de l'activité anticandidosique de Terminalia catappa Linn $\left(\mathrm{TEKAM}_{3}\right)$, un extrait de Combretaceae de la pharmacopée ivoirienne, Bulletin de la Société Royale des Sciences de Liège, 2008; 77 : 120-136.

3. Ahon M. G., Akapo-Akue J. M., Kra Mathieu A., Ackah J. B., Zirihi N. G., Djaman J. A. Antifungal activity of the aqueous and hydro-alcoholic extracts of Terminalia superba Engl. on the in vitro growth of clinical isolates of pathogenic fungi. Agriculture and Biology Journal of North America, $2011 ; 2: 250-257$.

4. Andriantsoa M. et Andriantsiferana R. Mise en évidence d'une éventuelle propriété antibactérienne chez quelques extraits de plantes utilisées à Madagascar pour lutter contre les manifestations diarrhéiques, Archive du Centre National de Recherche Pharmaceutique, 19832 : 179-183.

5. Andriantsoa M., Andriantsiferana R. Contribution à l'étude des propriétés antibactériennes de Terminalia mantaly, Archive du Centre National de Recherche Pharmaceutique, $1983 ; 2$ :184- 187.

6. Baba-Moussa F., Akpagana K., Bouchet P. Antifungical activities of seven West African Combrtaceae used in traditional medicine, J. Ethnopharmacogicol, 1999; 66: 335338.

7. Bolou G. E.K, Bagré I., Ouattara K. and Djaman A. J. Evaluation of the antibacterial activity of 14 medicinal plants in Côte d'Ivoire, Tropical Journal of Pharmaceutical Research, 2011; 10 (3): 335-340.

8. Bourkiss M., Hnach M., Bourkiss B., Ouhssine M., Chaouch A. Composition chimique et propriétés antibactériennes des huiles essentielles extraites des feuilles de Tetraclinis articulata (Vahl) du Maroc, Afrique Science, 2007 ; 03 (2): $232-242$. studied. The most sensitive strains were S. aureus. The hydroalcoholic extract (70/30) concentrate most the active ingredient of plants studied. Further studies will produce a series of chromatography to optimize the active ingredients, and determine the chemical compounds responsible for the antibacterial activity of Terminalia mantaly.

\section{ACKNOWLEGEMENT}

Special thanks to the National Laboratory of Public Health for their support during the course of this work.

9. Joshi R. K., Mujawar M.H.; K., Badakar V. M., et Khatib N. A. In vitro antimicrobial activity of the essential oil of Erigeron floribundus. International Journal of Research in Ayurveda \& Pharmacy, 2011; 2 (1): 236-238

10. Mann A., Yahaya Y., Banso A. and John F. Phytochemical and antimicrobial activity of Terminalia avicennioides extracts against some bacteria pathogens associated with patients suffering from complicated respiratory tract diseases, Journal of medical plants Research, 2008; 2 (5): 94-97.

11. Millogo H., Guisso L. P., Nacoulma O. O. Savoir traditionnel et médicaments traditionnels améliorés. Centre Européen de Santé Humanitaire, Lyon, 2006 ; 9p

12. Nacoulma O. O. Plantes médicinales et pratiques médicales traditionnelles au Burkina Faso : cas du plateau central, Thèse de Doctorat ès Sciences Naturelles. Université de Ouagadougou Burkina Faso1996; 605p.

13. N'Guessan K., Kadja B., Zihiri G. N., Traoré D., Aké A. L. Screening phytochimique de quelques plantes médicinales ivoiriennes utilisées en pays Krobou (Agboville, Côte d'Ivoire). Sciences \& Nature, $2009 ; 6: 1-15$

14. Rivière C., Nicolas J.-P., Caradec M.-L., Désiré O., Schmitt A. Les plantes médicinales de la région nord de Madagascar : une approche éthnopharmacologique, Bulletin de la Société Française d'Ethnopharmacologie, 2005; 36 : 36- 49

15. Yayé Y. G., Kra A. K. M., Ackah J. A. A. B. et Djaman A. J. Évaluation des l'activité antifongique et essai de purification des extraits de Terminalia mantaly (H.Perrier), une Combretaceae sur la croissance in vitro de Candida albicans. Bulletin de la Société Royale des Sciences de Liège, 2011; $80: 953-964$

16. Zihiri G. N., Kra A. M. et Guédé-Guina F. Evaluation de l'activité antifongique de Microglossa pyrifolia (Lamarck) O. Kunze (Asteraceae) «PYMI» sur la croissance in vitro de Candida albicans, Revue de Méd. \& Pharma. Afr, 2003; 17:11-18. 